\title{
Współpraca transgraniczna a rozwój regionów wschodnich
}

\section{Wstęp}

Współpraca transgraniczna jest jednym $\mathrm{z}$ istotnych elementów współpracy międzynarodowej. W Europie historia tej współpracy sięga lat 50. ubiegłego wieku. W wyniku zmian politycznych od początku lat 90. w Europie Środkowej i Wschodniej pojawiały się pierwsze formy współpracy na terenach przygranicznych. W procesie tym uczestniczy również Polska, na terenie której działa 16 euroregionów. Współdziałanie regionów przygranicznych wynika z potrzeby łagodzenia niekorzystnych skutków istnienia granic i zmniejszania dystansu rozwojowego na tych obszarach. Polskie regiony przygraniczne sa bardzo zróżnicowane pod względem rozwoju, szczególnie słabo rozwinięte są tereny położone wzdłuż granicy wschodniej. Dlatego też istotnym elementem polskiej polityki regionalnej jest wyrównywanie różnic $w$ poziomie rozwoju obszarów przygranicznych. Może on odbywać się przez współpracę transgraniczną, która jest szansą na rozwój lokalny i regionalny, szczególnie w aspekcie możliwości wykorzystania środków finansowych z programów współpracy transgranicznej Unii Europejskiej.

Celem opracowania było wskazanie korzyści i barier rozwoju obszarów przygranicznych wynikających ze współpracy transgranicznej na przykładzie regionów wschodnich z uwzględnieniem euroregionów Niemen, Bug i Karpaty.

\section{Rozwój regionalny a współpraca transgraniczna}

Współpraca transgraniczna jest rozumiana jako łącznik między polityką regionalną a procesami integracyjnymi. Rozwój regionalny jest procesem pozytywnych zmian o charakterze wzrostu ilościowego i postępie jakościowym zachodzących $w$ danym układzie regionalnym, z uwzględnieniem potrzeb, ce- 
lów, preferencji i hierarchii wartości, które składają się na jego gospodarkę ${ }^{1}$. Rozwój jest zjawiskiem dynamicznym, a jego kierunek określają wyznaczone cele. ,Z celami związane są zadania, służące ich osiagnięciu, zawarte w programach lub strategiach rozwoju, takie jak tworzenie klimatu do lokalizacji i dobrego funkcjonowania podmiotów gospodarczych, budowy nowych zakładów, wzrostu zatrudnienia itp., wraz z określeniem czynników rozwoju. Czynniki te $\mathrm{z}$ reguły obejmują następujące zagadnienia:

- walory użytkowe wytworzone przez naturę (np. bogactwa naturalne, gleby);

- walory użytkowe wytworzone przez ludzi (np. obiekty produkcyjne, infrastruktura);

- $\quad$ siłę roboczą (wielkość i strukturę, kwalifikacje, motywacje do pracy itp.);

- kulturę i tradycje gospodarcze danego obszaru (np. osiagnięcia gospodarcze);

- instytucje zajmujące się rozwojem i promocją danego obszaru (np. banki, inkubatory przedsiębiorczości, agencje rozwoju);

- atrakcyjność miejsc przebywania (np. zagospodarowanie terenu, stan środowiska)"2.

Zarządzanie rozwojem regionalnym jest podstawą działalności władz lokalnych i regionalnych. To władze decydują o kierunku rozwoju regionu na podstawie analiz strategicznych. W tym celu konieczne jest określenie polityki regionalnej, która ustala cele i środki kształtowania zagospodarowania w określonych warunkach. Na terenach przygranicznych jednym $\mathrm{z}$ istotnych elementów uwzględnianych $w$ strategiach rozwoju regionu jest współpraca przygraniczna. Władze samorządowe i ludność obszarów przygranicznych przez współpracę transgraniczną widzą możliwość rozwoju. W Polsce rozwój regionów przygranicznych został włączony do polityki regionalnej. Rozwój regionów przygranicznych ma strategiczne znaczenie w polityce rozwoju regionalnego Polski, ponieważ 11 województw to regiony przygraniczne ${ }^{3}$. W aspekcie integracji z Unią Europejską rozwój obszarów przygranicznych odbywa się przy wsparciu finansowym, co dodatkowo sprzyja rozwojowi tych obszarów.

Współpraca transgraniczna umożliwia, ,rozprzestrzenianie się innowacji gospodarczych oraz przenikanie wpływów społeczno-kulturalnych"4 różnych

\footnotetext{
${ }^{\text {I} P o r . ~ W i a t r a k ~ A . P .: ~ Z a r z a ̨ d z a n i e ~ g o s p o d a r k a ̨ ~ r e g i o n a l n a ̨ ~ i ~ l o k a l n a ̨ . ~[w:] ~ B o j a r ~ E ., ~ P l a w g o ~ B . ~(r e d .): ~}$ Zarządzanie rozwojem regionalnym i lokalnym. Nauka-Edukacja, Warszawa 2000, s. 83-84.

${ }^{2}$ Ibidem, s. 84.

${ }^{3}$ Ładysz J.: Problemy współpracy transgranicznej ze szczególnym uwzględnieniem peryferyjnych regionów wschodnich. [w:] Bołtromiuk A. (red.): Regiony peryferyjne w perspektywie polityki strukturalnej Unii Europejskiej. Wydaw. Uniwersytetu w Białymstoku, Białystok 2003, s. 156.

${ }^{4}$ Mierosławska A.: Bariery rozwoju współpracy transgranicznej gmin na pograniczu wschodnim. IERiGŻ. Komunikaty, Raporty, Ekspertyzy. Warszawa 2003, nr 483, s. 7.
} 
narodów. Daje możliwość nawiązania bezpośredniej współpracy, wymiany gospodarczej, naukowej, technicznej i technologicznej. Dzięki współpracy transgranicznej region może wspólnie wykorzystywać i wzajemnie uzupełniać zasoby czynników produkcji (siłę robocza, kapitał, zasoby naturalne itp.). Współpraca przygraniczna jest szansą na wyrównanie różnic wynikających z peryferyjności obszaru (w stosunku do centrum kraju) i istnienia granicy (np. różny poziom życia po obu stronach granicy). Często staje się ona atutem konkurencyjnym regionu, a to przyciaga inwestorów z kraju i z zagranicy. Wzrasta atrakcyjność regionu, zarówno inwestycyjna (firmy przez taką lokalizacje widzą możliwość zbytu swoich produktów na rynku zagranicznym oraz szukają tańszego, lepszego pod względem jakości rynku zaopatrzenia), jak też turystyczna (np. wynikająca ze swobody ruchu przygranicznego).

Współpraca transgraniczna może przybierać różne formy, jedną z nich jest stworzenie euroregionu. Euroregiony są to obszary współpracy transgranicznej powstające $w$ wyniku porozumienia między jednostkami samorządu terytorialnego dwóch lub więcej państw. Współpraca w ramach euroregionu odbywa się na podstawie prawa wewnętrznego danego kraju oraz zgodnie $\mathrm{z}$ prawem międzynarodowym. Najważniejszymi aktami prawnymi dotyczącymi współpracy transgranicznej są:

- Europejska konwencja ramowa o współpracy transgranicznej między wspólnotą a władzami terytorialnymi,

- Europejska Karta Regionów Granicznych i Transgranicznych,

- Europejska Karta Samorządu Terytorialnego,

- Europejska Karta Samorządu Regionalnego.

\section{Działalność euroregionów w Polsce}

Do końca 2002 r. w Polsce funkcjonowało 16 euroregionów ulokowanych na wszystkich granicach (tab. 1). Polska część euroregionów obejmuje około 160 tys. $\mathrm{km}^{2}$ powierzchni i zamieszkuje ją ponad $15 \mathrm{mln}$ osób $^{6}$. Na granicy północnej funkcjonuje euroregion Bałtyk, na granicy wschodniej euroregiony: Niemen, Bug, Karpaty i Puszcza Białowieska, na granicy południowej euroregiony: Tatry, Beskidy, Śląsk Cieszyński, Silesia, Pradziad, Glacensis i Dobrava, a na granicy zachodniej euroregiony: Nysa, Sprewa-Nysa-Bóbr, Viadrina i Pomerania. Największym pod względem obszaru jest euroregion Karpacki, później Bug, Bałtyk i Niemen. Pierwszy euroregion „Nesse-Nisa-Nysa” po-

\footnotetext{
${ }^{5}$ Polski Portal Rozwoju. http://www.pldg.pl/p/pl/TarJ/6/8/4/

${ }^{6}$ Euroregiony na granicach Polski. Urząd Statystyczny we Wrocławiu, Wrocław 2001.
} 
wstał w 1991 r. na granicy zachodniej, ostatni - Puszcza Białowieska - w 2002 r. na granicy polsko-białoruskiej (jeszcze w trakcie realizacji). W 2003 r. rozpoczeły się prace nad utworzeniem kolejnego euroregionu na granicy polsko-rosyjskiej pod wstępnį nazwą Łyna-Ława.

\section{Tabela 1}

Euroregiony w Polsce

\begin{tabular}{|c|l|l|c|c|l|}
\hline Lp. & \multicolumn{1}{|c|}{$\begin{array}{c}\text { Nazwa } \\
\text { euroregionu }\end{array}$} & Siedziba & $\begin{array}{c}\text { Data } \\
\text { powstania }\end{array}$ & $\begin{array}{c}\text { Liczba } \\
\text { członków } \\
\text { po stronie } \\
\text { polskiej }\end{array}$ & \multicolumn{1}{|c|}{$\begin{array}{c}\text { Państwa } \\
\text { zintegrowane }\end{array}$} \\
\hline 1 & Nysa & Jelenia Góra & $1991^{\prime}$ & 60 & $\begin{array}{l}\text { Polska, Czechy, } \\
\text { Niemcy }\end{array}$ \\
\hline 2 & Karpaty & Krosno & 1993 & 1 & $\begin{array}{l}\text { Polska, Ukraina, } \\
\text { Stowacja, Węgry, } \\
\text { Rumunia }\end{array}$ \\
\hline 3 & $\begin{array}{l}\text { Nysa-Sprewa- } \\
\text {-Bóbr }\end{array}$ & Gubin & 1993 & 65 & Polska, Niemcy \\
\hline 4 & Viadrina & Słubice & 1993 & 28 & Polska, Niemcy \\
\hline 5 & Tatry & Nowy Targ & 1994 & 25 & Polska, Słowacja \\
\hline 6 & Bug & Chełm & 1995 & 4 & $\begin{array}{l}\text { Polska, Białoruś, } \\
\text { Ukraina }\end{array}$ \\
\hline 7 & Pomerania & Szczecin & 1995 & 89 & $\begin{array}{l}\text { Polska, Niemcy, } \\
\text { Szwecja }\end{array}$ \\
\hline 8 & Glacensis & Kłodzko & 1996 & 20 & Polska, Czechy \\
\hline 9 & Niemen & Suwałki & 1997 & 103 & $\begin{array}{l}\text { Polska, Białoruś, } \\
\text { Litwa }\end{array}$ \\
\hline 10 & Pradziad & Prudnik & 1997 & 18 & Polska, Czechy \\
\hline 11 & Bałtyk & Elblag & 1998 & 88 & $\begin{array}{l}\text { Polska, Rosja, } \\
\text { Litwa, Lotwa, } \\
\text { Szwecja }\end{array}$ \\
\hline 12 & $\begin{array}{l}\text { Śląsk } \\
\text { Cieszyński }\end{array}$ & Cieszyn & 1998 & 16 & Polska, Czechy \\
\hline 13 & Silesia & Racibórz & 1998 & 19 & Polska, Czechy \\
\hline 14 & Beskidy & Bielsko-Biała & 2000 & 26 & $\begin{array}{l}\text { Polska, Czechy, } \\
\text { Słowacja }\end{array}$ \\
\hline 15 & Dobrava & Wałbrzych & 2001 & 4 & Polska, Czechy \\
\hline 16 & $\begin{array}{l}\text { Puszcza } \\
\text { Białowieska }\end{array}$ & Hajnówka & 2002 & 9 & Polska, Białoruś \\
\hline
\end{tabular}

Źródło: Opracowanie wlasne na podstawie: Euroregiony na granicach Polski. Urząd Statystyczny we Wrocławiu, Wrocław 2001. 


\section{Współpraca transgraniczna wschodnich regionów Polski}

Współpraca transgraniczna na granicy wschodniej rozpoczęła się w latach 90. Pierwszy powstał w 1993 r. euroregion Karpaty, następny w 1995 r. - Bug, kolejny w 1997 r. - Niemen, a od 2002 r. w trakcie tworzenia jest euroregion Puszcza Białowieska.

Euroregion Karpaty obejmuje obszary przygraniczne Polski, Słowacji, Ukrainy, Rumunii i Węgier. Po stronie polskiej obszar euroregionu obejmuje 180 gmin z województwa podkarpackiego o łącznej powierzchni 18,6 tys. $\mathrm{km}^{2}$ zamieszkanej przez $2,3 \mathrm{mln}$ osób. Po stronie ukraińskiej obszar euroregionu ma 56,6 tys. $\mathrm{km}^{2}$ powierzchni, liczy 6,4 mln mieszkańców i obejmuje cztery obwody: 1wowski, zakarpacki, iwanofrankowski i czerniowiecki. W skład strony słowackiej wchodzą dwa obszary (koszycki i preszowski) o łącznej powierzchni 10,4 tys. $\mathrm{km}^{2}$ i liczbie ludności $1,1 \mathrm{mln}$. Po stronie węgierskiej w skład euroregionu wchodzi pięć obszarów (Borsod-Abauj-Zemplen, Hajdu-Bihar, Heves, Jasz-Nagykun-Szolnok, Szabolcs-Szatmar-Bereg) o łącznej powierzchni 28,6 tys. $\mathrm{km}^{2}$ i liczbie ludności $2,6 \mathrm{mln}$. Ze strony rumuńskiej w skład euroregionu wchodzi pięć okręgów (Bihor, Salaj, Satu Mare, Maramures, Botosani) o powierzchni 27,1 tys. $\mathrm{km}^{2}$ i liczbie ludności $2,3 \mathrm{mln}^{7}$. Euroregion ten powstał w celu zwiększenia współpracy pomiędzy sąsiadami w dziedzinie ekonomicznej, naukowej, kulturalnej, oświatowej, turystycznej i ekologicznej.

Euroregion Bug powstał w 1995 r. na podstawie umowy zawartej pomiędzy Polską a Ukrainą. W 1998 r. do współpracy przyłączyła się Białoruś. W skład euroregionu po stronie polskiej wchodzi 251 gmin $z 4$ województw (lubelskiego, mazowieckiego, podkarpackiego i świętokrzyskiego) o łącznej powierzchni 29,3 tys. $\mathrm{km}^{2}$ i liczbie ludności $2,7 \mathrm{mln}$. Po stronie ukraińskiej w skład euroregionu wchodzi obwód wołyński o obszarze 20,1 tys. $\mathrm{km}^{2}$ i liczbie ludności $1,1 \mathrm{mln}$, a po stronie białoruskiej obwód brzeski o powierzchni 32,8 tys. $\mathrm{km}^{2}$ z 1,5 mln mieszkańców. „Działalność euroregionu Bug polega na współpracy $\mathrm{w}$ dziedzinie zagospodarowania przestrzennego, komunikacji, transportu i łączności, oświaty, ochrony zdrowia, kultury, sportu i turystyki, ochrony i poprawy stanu środowiska naturalnego, likwidacji zagrożeń i klęsk żywiołowych, rozwijania kontaktów między mieszkańcami obszarów przygranicznych oraz współpracy instytucjonalnej i podmiotów gospodarczych"8.

W 1997 r. w Augustowie przedstawiciele Polski, Litwy i Białorusi podpisali porozumienie o utworzeniu Związku Transgranicznego Euroregion Nie-

\footnotetext{
${ }^{7}$ Euroregiony Polski. http://eurokraszak.kgb.pl/euroregiony.htm

${ }^{8} \mathrm{http}: / /$ eurokraszak.kgb.pl/EUROREGIONY/bug.htm
} 
men. Euroregion ten obejmuje obszar 46,6 tys. $\mathrm{km}^{2}$ i zamieszkuje go $2,78 \mathrm{mln}$ osób. Celem euroregionu jest rozwój współpracy transgranicznej w dziedzinach: zagospodarowania przestrzennego, komunikacji, transportu, łączności, oświaty, ochrony zdrowia, poprawy stanu środowiska i współpracy pomiędzy instytucjami państwowymi i podmiotami gospodarczymi.

Euroregion Puszcza Białowieska został utworzony na terenie transgranicznego obiektu przyrodniczego, jakim jest Puszcza Białowieska. Po stronie polskiej w skład euroregionu wchodzą: powiat hajnowski, miasto Hajnówka i gmina Białowieża, a po stronie białoruskiej rejony: kamieniecki, puźański, świsłocki ${ }^{9}$.

\section{Finansowanie współpracy transgranicznej szansą roz- woju euroregionów granicy wschodniej}

Sposoby finansowania współpracy transgranicznej określają zawarte porozumienia, w przypadku euroregionów są to zwykle ich statuty. Środki finansowe najczęściej pochodzą ze składek członków oraz darów i subwencji instytucji wspierających działalność euroregionu. W Unii Europejskiej współpraca transgraniczna jest włączona do polityki regionalnej i podlega finansowaniu $\mathrm{z}$ funduszy strukturalnych. Polska po włączeniu do UE do 2006 r. będzie korzystać $\mathrm{z}$ dofinansowania $\mathrm{z}$ programu PHARE, a później w ramach programu INTERREG oraz ze środków polityki strukturalnej. Obecnie władze samorządowe tworzące euroregiony moga korzystać $\mathrm{z}$ finansowania zewnętrznego, np. ze środków programów pomocowych Unii Europejskiej. Fundusze te stanowią istotną rolę w rozwoju i działalności euroregionów. W Polsce od 1994 r. istnieje możliwość dofinansowania współpracy transgranicznej $\mathrm{z}$ programu PHARE. W ramach Programu Współpracy Przygranicznej PHARE funkcjonuje Fundusz Małych Projektów Euroregionalnych (FMP), który wspiera realizację małych projektów (do 50000 euro dla pojedynczego projektu) oraz wydarzenia o naturze społecznej (kulturalne, sportowe, naukowe) ${ }^{10}$. Dotychczas środki pochodzące $\mathrm{z}$ FMP wykorzystywano do finansowania małych projektów w ramach programów:

- Współpracy Przygranicznej Polska - Niemcy,

- Współpracy Przygranicznej Polska - Czechy,

- Współpracy Przygranicznej Polska - Słowacja,

\footnotetext{
${ }^{9}$ Euroregion Puszcza Białowieska. http://sphajnowka.home.pl/euroregion/euroreg.html

${ }^{10}$ Por. Mierosławska A.: Bariery op.cit., s. 7, Aktualności PHARE, http://fundusze.ukie.gov.pl oraz Ładysz J.: Problemy..., op.cit., s. 157.
} 
- Współpracy Przygranicznej Polska - Region Morza Battyckiego,

- Zintegrowana Granica Wschodnia.

W latach 1994-2003 dofinansowanie współpracy transgranicznej z FMP dotyczyło 352 zakończonych projektów na kwotę 507,9 $\mathrm{mln}$ eưro oraz 182 projektów nadal realizowanych za łączną kwotę $627,8 \mathrm{mln}$ euro. Euroregiony na granicy wschodniej realizują mniej projektów niż euroregiony $\mathrm{z}$ granicy zachodniej. Wśród projektów zakończonych dofinansowano 32 projekty w ramach „Zintegrowany Program na Granicy Wschodniej COP 1996, COP 1997, COP 1999, COP 2000" na łączną kwotę 91,6 mln euro, co stanowiło $18 \%$ ogółu dofinansowania. Obecnie na granicy wschodniej realizowanych jest 17 projektów w ramach ,Zintegrowanego Programu na Granicy Wschodniej PNP 2001, 2002 i 2003 " na kwotę 153,4 mln euro, co stanowi 24,4\% ogółu dofinansowania (por. tabela 2).

Do października $2001 \mathrm{r}$. najwięcej projektów (658) zrealizowano w euroregionie Nysa, regiony wschodnie były daleko w tyle. Euroregion Niemen zrealizowal 53 projekty, a euroregion Bug $-16^{11}$. Dotychczasowe wsparcie z programów UE dla współpracy transgranicznej na pograniczu wschodnim jest niéwielkie w kontekście wsparcia innych regionów. Jednak potencjalną szansą rozwoju regionów wschodnich po uzyskaniu przez Polskę członkostwa jest możliwość korzystania $\mathrm{z}$ funduszy Unii Europejskiej $\mathrm{w}$ ramach programu INTERREG, gdzie około $80 \%$ środków przeznaczono na współpracę transgraniczna, a główny nacisk został położony na programy realizowane na granicy wschodniej (około $35 \%$ ogółu środków).

\section{Tabela 2}

Realizowane i zakończone programy w ramach Zintegrowanej Granicy Wschodniej

\begin{tabular}{|c|c|c|c|c|c|c|}
\hline Lp. & Nazwa programu & $\begin{array}{c}\text { Koniec } \\
\text { kontrakto- } \\
\text { wania do: }\end{array}$ & $\begin{array}{c}\text { Koniec } \\
\text { płatności } \\
\text { do: }\end{array}$ & $\begin{array}{c}\text { Budżet } \\
\text { programu } \\
\text { (min EUR) }\end{array}$ & \begin{tabular}{|c|} 
Budżet \\
programu \\
$\left(\mathrm{m} \ln \mathrm{PLN}^{*}\right)$ \\
\end{tabular} & $\begin{array}{l}\text { Liczba } \\
\text { projek- } \\
\text { tów }\end{array}$ \\
\hline 1 & 2 & 3 & 4 & 5 & 6 & 7 \\
\hline \multicolumn{7}{|c|}{ PROGRAMY REALIZOWANE } \\
\hline 1 & $\begin{array}{l}\text { Zintegrowany Program } \\
\text { na Granicy Wschodniej } \\
\text { (PNP) } 2001\end{array}$ & 03-12-15 & $04-12-15$ & 40,8 & 163,2 & 9 \\
\hline 2 & $\begin{array}{l}\text { Zintegrowany Program } \\
\text { na Granicy Wschodniej } \\
\text { (PNP) 2002, cz. I }\end{array}$ & $04-07-31$ & $05-07-31$ & 11,0 & 44,0 & 1 \\
\hline 3 & $\begin{array}{l}\text { Zintegrowany Program } \\
\text { na Granicy Wschodniej } \\
\text { (PNP) 2002, cz. II }\end{array}$ & 04-11-30 & $05-11-30$ & 31,5 & 126,0 & - \\
\hline
\end{tabular}

${ }^{11}$ Ladysz J.: Problemy..., op.cit., s. 163. 
cd. tabeli 2

\begin{tabular}{|c|c|c|c|c|c|c|}
\hline 1 & 2 & 3 & 4 & 5 & 6 & 7 \\
\hline 4 & \begin{tabular}{|l|} 
Zintegrowany Program na \\
Granicy Wschodniej \\
(PNP) 2002, cz. III
\end{tabular} & $|04-11-30|$ & $05-11-30$ & 13,6 & 54,5 & - \\
\hline 5 & \begin{tabular}{|l|} 
Zintegrowany Program na \\
Granicy Wschodniej \\
(PNP) 2003, cz. I
\end{tabular} & $|05-11-30|$ & $06-11-30$ & 1,5 & 6,0 & - \\
\hline 6 & $\begin{array}{l}\text { Zintegrowany Program na } \\
\text { Granicy Wschodniej } \\
\text { (PNP) 2003, cz. II }\end{array}$ & $05-11-30$ & $06-11-30$ & 47,0 & 187,8 & 5 \\
\hline 7 & $\begin{array}{l}\text { Przyszła Granica Wschod- } \\
\text { nia (PNP) 2003, cz. II }\end{array}$ & $05-11-30$ & $06-11-30$ & 8,0 & 24,0 & 2 \\
\hline \multicolumn{4}{|c|}{ Razem } & 153,4 & 605,5 & 17 \\
\hline \multicolumn{4}{|c|}{ Kączne finansowanie wszystkich projektów } & 627,8 & 2503,34 & 182 \\
\hline \multicolumn{7}{|c|}{ PROGRAMY ZAKOŃCZONE } \\
\hline 1 & $\begin{array}{l}\text { Inwestycje na Granicy } \\
\text { Wschodniej COP } 1996 \\
\end{array}$ & $|99-12-31|$ & $00-12-31$ & 2,6 & 10,4 & 3 \\
\hline 2 & \begin{tabular}{|l|} 
Zintegrowany Program na \\
Granicy Wschodniej - \\
COP 1997
\end{tabular} & $99-12-31$ & $00-12-31$ & 15,0 & 60,0 & 7 \\
\hline 3 & \begin{tabular}{|l|} 
Zintegrowany Program na \\
Granicy Wschodniej - \\
COP 1998
\end{tabular} & $00-12-31$ & $00-12-31$ & 13,0 & 52,0 & 6 \\
\hline 4 & $\begin{array}{l}\text { Zintegrowany Program na } \\
\text { Granicy Wschodniej - } \\
\text { COP 99 }\end{array}$ & $01-09-30 \mid$ & $02-09-30$ & 17,5 & 52,0 & 7 \\
\hline 5 & \begin{tabular}{|l|} 
Zintegrowany Program na \\
Granicy Wschodniej \\
(COP) 2000
\end{tabular} & $02-10-31$ & $03-10-31$ & 43,5 & 156,0 & 9 \\
\hline \multicolumn{4}{|c|}{ Razem } & 91,6 & 330,4 & 32 \\
\hline \multicolumn{4}{|c|}{ Łączne finansowanie wszystkich projektów } & 507,9 & 1994,6 & 352 \\
\hline
\end{tabular}

*PLN liczone wg kursu 1 euro $=4$ PLN

Żródlo: Opracowanie własne na podstawie Zintegrowana granica wschodnia. Władza Wdrażająca Program Współpracy Przygranicznej. http://www.wwpwp.it.pl

\section{Korzyści ze współpracy transgranicznej regionów wschodnich}

Do korzyści wynikających $\mathrm{z}$ funkcjonowania regionów transgranicznych należy zaliczyć ${ }^{12}$ :

\footnotetext{
${ }^{12}$ Kożuch B. (red.): Rozwój gospodarczy i zmiany strukturalne w ujęciu regionalnym. Wydaw. Uniwersytetu w Białymstoku. Białystok 1997, tom I, s. 158-159.
} 
- rozwój i modernizację infrastruktury technicznej,

- nawiazywanie wzajemnych kontaktów w dziedzinie edukacji, kultury i nauki,

- współpracę w dziedzinie ochrony środowiska,

- zacieśnianie kontaktów i skoordynowanie działań w sferze ekonomiczno-społecznej,

- tworzenie korzystnych warunków do wspólnego rozwoju turystyki,

- harmonizacje regulacji prawnych oraz uaktualnienie obowiązujących i przygotowanie nowych porozumień i umów międzypaństwowych, - intensyfikację zagospodarowania przestrzennego.

W ramach współpracy transgranicznej na granicy wschodniej buduje się nowe, rozbudowuje i modernizuje przejścia graniczne i szlaki tranzytowe. W obszarze euroregionu Niemen w 2000 r. rozpoczęto modernizację i rozbudowę przejścia granicznego w Kuźnicy, na obszarze euroregionu Bug budowę przejścia $\mathrm{w}$ Dorohusku oraz rozbudowę i modernizację przejścia granicznego w Terespolu, a na terenie euroregionu Karpaty budowę przejścia granicznego w Krościenku i rozbudowę i modernizację przejścia granicznego w Hrebennem. Modernizacja infrastruktury technicznej na wschodnich obszarach przygranicznych obejmowała też sieć drogowa, np. w euroregionie Bug zmodernizowaną drogę do przejścia granicznego Sławatycze i drogę do Terespola; a na terenie euroregionu Niemen drogę krajową Białystok-Bobrowniki.

Do korzyści wynikających ze współpracy transgranicznej należy zaliczyć możliwość korzystania z funduszy zagranicznych, np. ISPA, PHARE. Euroregiony na pograniczu wschodnim zrealizowały 49 projektów finansowanych $\mathrm{z}$ funduszy pomocowych Unii Europejskiej. Przy wykorzystaniu funduszy pomocowych na terenie euroregionu Niemen powstała oczyszczalnia ścieków z systemem głównych kolektorów w Sejnach. W 2004 r. do końca lutego w ramach programu Funduszy Małych Grantów - polska granica wschodnia ogłoszono konkursy dotyczące projektów o charakterze transgranicznym. Biura euroregionów Niemen, Bug, Karpaty i Puszcza Białowieska zbierały propozycje dotyczące: lokalnego rozwoju gospodarczego, w tym turystyki, ochrony zdrowia, informacji i komunikacji, wymiany kulturalnej oraz szkoleń i edukacji w zakresie zatrudnienia. Dofinansowanie projektu $\mathrm{z}$ funduszu PHARE może wynieść maksymalnie $75 \%$ kosztów projektu - do 50 tys. euro. Warunkiem do spełnienia dla wnioskodawcy jest siedziba w polskiej części euroregionu, partnerzy również muszą pochodzić $z$ obszaru euroregionów państw tworzących go ${ }^{13}$.

\footnotetext{
${ }^{13}$ Por. wschodnie i północne euroregiony - możliwości dofinansowania projektów. http://www.regiony.nck.pl
} 
W ramach istniejących euroregionów na granicy wschodniej nawiązano współpracę w dziedzinie edukacji, kultury i nauki. Na terenie euroregionu Karpaty cyklicznie odbywają się seminaria pedagogiczno-oświatowe, które są forum spotkań nauczycieli. Od $1994 \mathrm{r}$. istnieje Stowarzyszenie Uniwersytetów Euroregionu Karpaty. W ramach współpracy transgranicznej realizowane są wspólne imprezy kulturalne, np. festiwale folklorystyczne Eurofolk oraz Festiwal Kultury Karpackiej. Do ważnych osiagnięć należy zaliczyć również Euroregionalną Olimpiadę Młodzieży Niepełnosprawnej, Jarmark Open-Folk, Konferencję Rektorów Wyższych Uczelni Regionu Karpackiego, Międzynarodową Konferencję Naukowo-Techniczną pt. „Ekologiczne i ekonomiczne uwarunkowania rozwoju gospodarczego Karpat Południowo-Wschodnich"14. Na terenie euroregionu Bug zorganizowano Międzynarodowy Festiwal Sportu Dzieci i Młodzieży w Zamościu, Regionalny Przegląd Akordeonowy, Dni Chełma Kultura bez granic, Turniej inauguracyjny Ligi Euroregionu Bug w koszykówce, konferencję popularnonaukową „Zamojszczyzna i Wołyń w minionym tysiącleciu - historia, nauka, sztuka". Wszystkie wymienione projekty były realizowane z udziałem partnerów zagranicznych $\mathrm{z}$ euroregionu $\mathrm{Bug}^{15}$.

$\mathrm{Na}$ obszarach wszystkich euroregionów położonych na granicy wschodniej podjęto współpracę $\mathrm{w}$ dziedzinie ochrony środowiska. Głównie dotyczyła ona monitoringu, ale też euroregiony podejmują działania mające na celu wspólne oczyszczanie i przeciwdziałanie zanieczyszczeniom środowiska.

Wiele działań na obszarach granicy wschodniej dotyczy zacieśniania kontaktów i skoordynowania działań w sferze ekonomiczno-społecznej. Przejawiają się one w promocji i wspomaganiu wspólnych przedsięwzięć gospodarczych, np. promocja Bieszczad, promocja euroregionu Bug, wspólne działania przez budowę sieci komunikacyjnych i rozbudowę przejść granicznych. Działania dotyczą też aktywizacji małych miast przez rozwój drobnej przedsiębiorczości i rzemiosła, np. euroregion Bug realizował projekt „Aktywizacja kontaktów gospodarczych pomiędzy regionem lubelskim i okręgiem wołyńskim", w euroregionie Karpackim istnieje współpraca Rzeszowa z Koszycami oraz współpraca $\mathrm{z}$ obwodem lwowskim. Ważnym elementem współpracy transgranicznej jest budowanie lokalnego partnerstwa, przykładem takiej współpracy jest euroregion Bug. Kontakty transgraniczne przejawiają się poprawą współdziałania pomiędzy policją urzędami celnymi i służbami ochrony granic, dzięki czemu zmniejsza się przestępczość transgraniczna.

Do korzyści ze współpracy transgranicznej na granicy wschodniej należy zaliczyć tworzenie warunków do wspólnego rozwoju turystyki. Na terenie eu-

\footnotetext{
${ }^{14}$ Euroregiony Polski. http://slimak.sciaga.pl

${ }^{15}$ Projekty euroregionalne. http://www.euroregion-bug.w4u.pl
} 
roregionu Karpaty planowane jest poprowadzenie ruchu turystycznego dzięki budowie linii kolejowej Sanok-Humenne (Słowacja) oraz uruchomienie na szlakach górskich małych przejść granicznych, na obszarze euroregionu Bug wspólnie z miastem Wołodzimierz Wołyński utworzono Biuro Obsługi Ruchu Turystycznego $\mathrm{w}$ Zwierzyńcu ${ }^{16}$. Na terenie Puszczy Białowieskiej zawiązano porozumienie transgraniczne dotyczące m.in. promocji parku przyrody.

Korzyścią ze współpracy transgranicznej dla obszarów przygranicznych jest intensyfikacja zagospodarowania przestrzennego przez wspólne sporządzanie transgranicznych planów zagospodarowania przestrzennego, wskazywanie na problemy przestrzenne regionów granicznych i wspólne wdrażanie ładu przestrzennego. Funkcjonujace na granicy wschodniej euroregiony rozpoznały problemy zagospodarowania przestrzennego i przez wspólne programy chcą realizować ich założenia. Do problemów tych zaliczają: zanieczyszczenie środowiska, przestarzałą infrastrukturę, opóźnienie rozwojowe w stosunku do centrów itp.

\section{Bariery współpracy transgranicznej regionów wschodnich}

Współpraca transgraniczna na wschodzie Polski istnieje od połowy lat 90 ., jednak jej efekty są zdecydowanie mniejsze w porównaniu do terenów zachodnich. Jest to wynikiem wielu barier i ograniczeń utrudniających tę współpracę. Przyczynami barier są różnice w poziomie i tempie rozwoju społeczno-gospodarczego partnerów oraz dystans kulturowy i językowy przejawiający się brakiem znajomości języka, tradycji, kultury sassiada i słabym przepływem informacji. Wiele barier i utrudnień wynika $\mathrm{z}$ różnych uregulowań prawnych, różnych struktur instytucjonalnych i nierówności kompetencji instytucji po obu stronach granicy ${ }^{17}$.

Wymienione przeszkody wpływają na ograniczenie współpracy transgranicznej, należy więc je eliminować lub łagodzić ich oddziaływanie. W przypadku granicy wschodniej dokonano rozpoznania i określono bariery współpracy transgranicznej ${ }^{18}$. Z opinii gmin położonych przy wschodniej granicy wyni-

\footnotetext{
${ }^{16}$ Połączenie z Koszycami. Wspólnota. http://www.wspólnota.org.pl

${ }^{17}$ Por. Mierosławska A.: Bariery rozwoju wspólpracy transgranicznej gmin na pograniczu wschodnim. IERiGŻ, Komunikaty, Raporty, Ekspertyzy, Warszawa 2003 nr 483 s. 14-18.

${ }^{18}$ Badania przeprowadziła dr inż. A. Mierosławska z IERiGŻ w 49 gminach położonych przy wschodniej granicy $z$ trzech województw: podlaskiego, lubelskiego i podkarpackiego. Szerzej [w:] Mierosławska A.: Bariery..., op.cit., s. 26-43.
} 
ka, że największe ograniczenia stanowią finanse - czyli brak środków na prowadzenie takiej działalności, dalej ograniczenia gospodarcze (brak silnej reprezentacji podmiotów gospodarczych, brak systemu zabezpieczeń finansowych transakcji handlowych z partnerem zagranicznym), formalnoprawne (niestabilność przepisów), instytucjonalne i infrastrukturalne (mała przepustowość przejść granicznych), mniejsze zaś znaczenie mają bariery społeczne i środowiskowe. Dla gmin pogranicza wschodniego skomplikowana procedura uzyskiwania środków przedakcesyjnych i brak własnych środków stanowią największą barierę rozwoju współpracy transgranicznej. Potwierdzeniem tego faktu są trudności z wykorzystywaniem środków przedakcesyjnych z funduszów PHARE 2000 dla Polski Wschodniej i Śląska ${ }^{19}$. W rankingu barier na trzecim miejscu występuje brak silnej reprezentacji podmiotów, a na kolejnych miejscach brak systemu zabezpieczeń finansowych transakcji z partnerem zagranicznym i niestabilność przepisów partnera.

W opinii badanych euroregionów pogranicza wschodniego najistotniejszymi przeszkodami były mała przepustowość przejść granicznych i mała aktywność urzędów w nawiązywaniu współpracy transgranicznej, jak też wymieniane przez gminy: brak środków na prowadzenie takiej działalności, skomplikowana procedura uzyskiwania środków, brak systemu zabezpieczeń finansowych transakcji handlowych $\mathrm{z}$ partnerem zagranicznym $\mathrm{i}$ silnej reprezentacji podmiotów gospodarczych ${ }^{20}$.

\section{Perspektywy rozwoju współpracy transgranicznej na regionów wschodnich}

Proces integracji Polski z Unią Europejską powoduje, że wschodnia granica Polski stała się granicą Unii. Granica ta będzie pełnić funkcję integracyjną przez współpracę transgraniczną, ale też będzie barierą dla państw spoza UE. Działania Unii Europejskiej idą w kierunku „uszczelniania granic zewnętrznych", w tym granicy wschodniej, co może w konsekwencji ograniczyć współpracę w ramach euroregionów. Jednak ograniczanie takiej współpracy nie leży w interesie żadnej ze stron. Białoruś, Ukraina i Rosja są ważnymi partnerami o znaczeniu gospodarczym i militarnym, dlatego należy przewidywać, że współpraca pomiędzy euroregionami będzie dalej się rozwijać. Rozwój współpracy transgranicznej na granicy wschodniej będzie realizowany w zakresie

\footnotetext{
${ }^{19}$ Ibidem, s. 32.

${ }^{20}$ Dotyczy euroregionów: Niemen, Bug, Karpaty; na podstawie: Mierosławska A., op.cit., s. 34-36.
} 
rozbudowy przejść granicznych i dróg dojazdowych, jak też będzie przejawiał się likwidacją barier handlowych (np. takich jak brak wsparcia kredytowo-ubezpieczeniowego, brak umowy o ochronie inwestycji itp.).

\section{Zakończenie}

Współpraca transgraniczna jest szansą na rozwój lokalny. Przez tworzenie powiązań międzynarodowych aktywizuje się działania przedsiębiorstw, władz lokalnych, organizacji. Na terenach wschodniej Polski istnieja cztery euroregiony: Bug, Niemen, Karpaty i Puszcza Białowieska. W ramach współpracy transgranicznej na obszarach tych euroregionów realizowane są projekty rozwijające infrastrukturę lokalną, wspomagające działania rozwojowe i nawiązujące do współpracy w dziedzinie nauki i kultury. Jednak liczba realizowanych projektów i ich zasięg są minimalne. Wynika to $\mathrm{z}$ wielu barier ograniczających współpracę, a w efekcie rozwój regionów. Zidentyfikowanie barier i ich eliminacja $\mathrm{w}$ przyszłości może rozwinąć współpracę transgraniczna, a to będzie szansą na dalszy rozwój tych regionów.

\section{Literatura}

BIALOBRZESKA R., MARKS-BIELSKA R.: Perspektywy rozwoju wschodnich regionów Polski w kontekście procesów globalizacji i integracji. [w:] Bołtromiuk A. (red.): Regiony peryferyjne w perspektywie polityki strukturalnej Unii Europejskiej. Wydaw. Uniwersytetu w BIAŁYMSTOKU, BIAŁYSTOK 2003.

Białobrzeska R., Kisiel R.: Udział instytucji rządowych i pozarządowych w podejmowaniu działań na rzecz rozwoju lokalnej współpracy transgranicznej. Strategie rozwoju lokalnego. Aspekty instytucjonalne. Wydaw. SGGW, Warszawa 2003, t.

Euroregiony na granicach Polski. Urząd Statystyczny we Wrocławiu, Wrocław 2001. Euroregiony Polski. http://eurokraszak.kgb.pl/euroregiony.htm Euroregion Puszcza Białowieska. http://sphajnowka.home.pl/euroregion/euroreg.html Euroregiony Polski. http://slimak.sciaga.pl

ŁADYSZ J.: Problemy współpracy transgranicznej ze szczególnym uwzględnieniem peryferyjnych regionów wschodnich. [w:] Bołtromiuk A. (red.): Regiony peryferyjne W perspektywie polityki strukturalnej Unii Europejskiej. Wydaw. Uniwersytetu w Białymstoku, Białystok 2003.

http://eurokraszak.kgb.pl/EUROREGIONY/bug.htm

KOŻUCH B. (red.): Rozwój gospodarczy i zmiany strukturalne w ujęciu regionalnym.

Wydaw. Uniwersytetu w Białymstoku. Białystok 1997 r., tom I.

MIEROSŁAWSKA A.: Bariery rozwoju współpracy transgranicznej gmin na pograniczu wschodnim. IERiGŻ, Komunikaty, Raporty, Ekspertyzy. Warszawa 2003, nr 483. 
Połączenie z Koszycami. Wspólnota. http://www.wspólnota.org.pl

Projekty euroregionalne. http://www.euroregion-bug.w4u.pl

Polski Portal Rozwoju. http://www.pldg.pl/p/pl/TarJ/6/8/4/

Wschodnie i północne euroregiony - możliwości dofinansowania projektów. $\mathrm{http}: / /$ www.regiony.nck.pl

WIATRAK A.P.: Zarządzanie gospodarką regionalną i lokalną. [w:] Bojar E., Plawgo B. (red.): Zarządzanie rozwojem regionalnym i lokalnym. Nauka-Edukacja, Warszawa 2000.

Zintegrowana granica wschodnia. Władza Wdrażająca Program Współpracy Przygranicznej. http://www.wwpwp.it.pl

\section{Cross-border Cooperation and the Development of Eastern Regions}

\section{Abstract}

The cross-border cooperation is an element of international cooperation allowing border areas to develop. Polish border areas are very much diversified . in respect of the development, especially weakly developed are terrains situated along eastern border. The chance of the development of those regions is to cooperate, especially in the aspect of using financial resources form programs of cross-border cooperation of the European Union. The aim of the study is to point benefits and barriers of border areas development caused by the crossborder cooperation on the example of eastern regions, taking into consideration euro regions: Neman, Bug and Carpathians. 